\title{
USABILITY USER INTERFACE DESAIN PADA APLIKASI ECOMMERCE (STUDI KOMPARASI TERHADAP PENGALAMAN PENGGUNA SHOPEE, LAZADA, DAN TOKOPEDIA)
}

\author{
Ali Muqoddas ${ }^{1}$, Auria Farantika Yogananti ${ }^{2}$, Henry Bastian ${ }^{3}$ \\ ${ }^{1,2,3}$ Program Studi Desain Komunikasi Visual, Fakultas Ilmu Komputer, Universitas Dian Nuswantoro \\ ali.muqoddas@gmail.com ${ }^{1}$, yogananti.au@dsn.dinus.ac.id ${ }^{2}$, henry@dsn.dinus.ac.id ${ }^{3}$
}

\begin{abstract}
Abstrak
Di Indonesia, kegiatan jual beli telah bergeser dari kegiatan jual beli secara tradisional ke elektronik. Hal ini dibuktikan dengan semakin menjamurnya aplikasi ecommerce yang berbanding lurus dengan jumlah orang yang telah mengunduhnya. Dengan banyaknya aplikasi ecommerce yang ada, setiap orang memiliki penilaian masing-masing ketika menggunakan aplikasi tersebut. Hal Ini dapat dilihat pada jumlah rating nilai pengguna pada tiap aplikasi ecommerce. Penilaian tersebut dapat bergantung dari pengalaman pengguna (User Experience) saat menggunakan aplikasi ecommerce, yaitu ketika pengguna bersinggungan langsung dengan Graphic User Inteface (GUI). GUI membuat aplikasi lebih mudah digunakan karena adanya tampilan grafis pada layar. Menurut ISO 9241-11, usability adalah bentuk ukuran sejauh mana sebuah produk dapat digunakan oleh pengguna untuk mencapai tujuan tertentu dengan efektivitas, efisiensi dan kepuasan dalam konteks penggunaan produk. Pada penelitian ini, dilakukan sebuah studi komparasi mengenai usability desain user interface pada beberapa aplikasi ecommerce dengan menggunakan analisa System Usability Scale (SUS). Studi komparasi ini diaplikasikan pada 3 aplikasi ecommerce dengan jumlah pengunduh tertinggi yaitu Shopee, Lazada dan Tokopedia. Hasil yang didapatkan dari studi komparasi usability pada beberapa aplikasi tersebut menunjukan bahwa usability dari ketiga aplikasi ecommerce ini masuk dalam range $O K$ dan GOOD, dimana Shopee memiliki nilai yang paling tinggi dibandingkan Lazada dan Tokopedia.
\end{abstract}

Kata Kunci: ecommerce, komparasi, pengalaman pengguna, usability

\begin{abstract}
In Indonesia, buying and selling activities have shifted from traditional to electronics this matter proved by the e-commerce applications widespread that are directly proportional to the number of people who have downloaded it. With so many e-commerce applications available, everyone has their ain judgment when using an application. It can be seen in the number of ratings on each e-commerce applications. The judgment depends on the user experience when using the ecommerce application when the user indirectly contacts with the Graphic User Interface (GUI). The GUI makes the program easier to use because of the graphical display on the screen. According to ISO 9241-11, usability is a form of measurement to check how far a product can be used to achieve certain goals with effectiveness, efficiency, and satisfaction in the context of product use. This comparative study applied to three e-commerce applications with the highest number of downloaders named Shopee, Lazada, and Tokopedia. This comparative study was applied to 3 e-commerce applications with the highest number of downloaders namely Shopee, Lazada, and Tokopedia. The result obtained from comparative studies of usability in some applications indicates that the usability of the three e-commerce applications went to grade $\mathrm{OK}$ and GOOD, where Shopee has a higher value compared to Lazada and Tokopedia.
\end{abstract}

Keywords: comparative, ecommerce, usability, user experience 


\section{PENDAHULUAN}

Di Indonesia, kegiatan jual beli telah bergeser dari kegiatan jual secara tradisional ke kegiatan jual beli secara modern. Kegiatan jual beli secara tradisional mengharuskan konsumen langsung datang ke pasar, toko atau swalayan yang menyediakan barang kebutuhan yang dicari sedangkan kegiatan jual beli secara modern tidak mengharuskan konsumen untuk langsung melihat barang yang dicari karena semuanya dilakukan melalui online pada website. Pergeseran ini dibuktikan dengan perkembangan pasar ecommerce Indonesia yang sangat pesat dan mencapai $\$ 200$ juta. Adapun platform yang digunakan adalah ecommerce Brands to Brand (B2B), Customers to Customers (C2C) dan Brand to Customers (B2C). Dalam ketiga platform ecommerce yang ada terdapat beberapa platform lagi yang berada dibawahnya seperti Marketplace platform dan Classifields / Person to Person Platform dibawah C2C platform dan Mainstream, Etailer, Daily Deals, dan Verticals platform dibawah B2C platform (Ho, 2016). Namun, tidak hanya melalui website, perkembangan pasar ecommerce Indonesia juga berkembang melalui aplikasi mobile dengan sebutan mobile commerce (mcommerce).

Di Indonesia, Tokopedia pertama kali meluncurkan aplikasi mobile untuk platform android pada tahun 2014 (Yusuf, 2014). Menyusul setelahnya pada tahun 2015 Lazada (Pratama, 2015) dan kemudian shopee (R., 2015). Ketiga perusahaan tersebut bila dilihat dari platform Android melalui Google Play Store merupakan 3 perusahaan teratas untuk aplikasi Top Free Shopping. Bila dilihat dari platform Android dalam gambar 1, gambar 2 dan gambar 3, ketiganya telah diunduh lebih dari 10 Miliyar. Aplikasi Shopee mendapatkan rating 4.2 berdasarkan 400ribu lebih vote, Lazada mendapatkan rating 4.2 berdasarkan 1 juta lebih vote sedangkan total aplikasi Tokopedia mendapatkan rating 4.3 berdasarkan 700 ribu lebih vote.
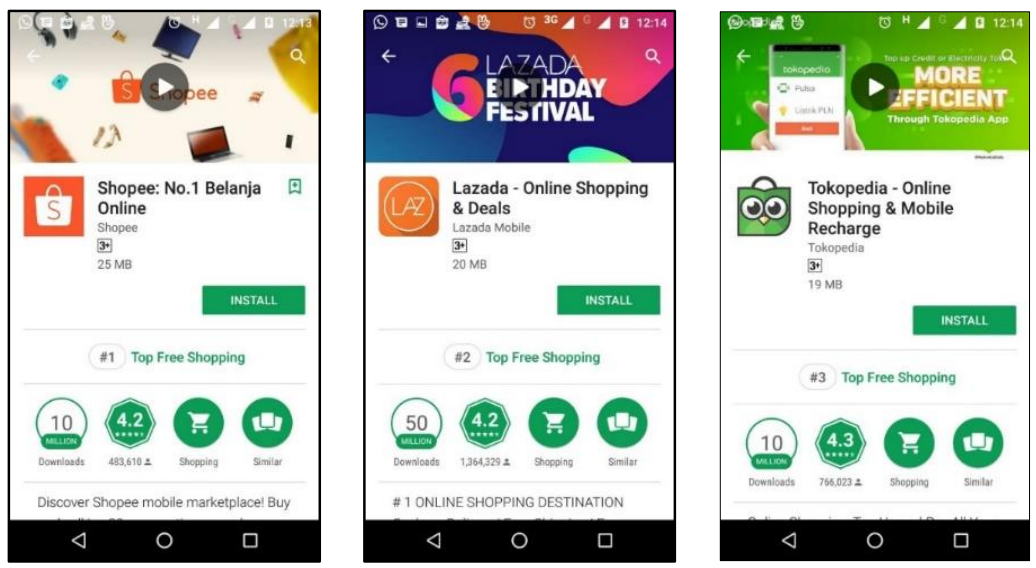

Gambar 1. Tampilan laman aplikasi Shopee (kiri), Lazada (tengah), dan Tokopedia (kanan) dalam platform Android-Google Play Store

[Sumber: Dokumentasi Penulis]

Tidak mudah untuk menjelaskan dari mana standar bintang yang terdapat didalam rating yang diberikan, namun pilihan pengguna untuk memberikan bintang dapat bergantung saat pengguna berinteraksi dengan aplikasi dalam hal ini pengguna akan bersinggungan langsung dengan Graphic User Interface (GUI). GUI membuat program 
lebih mudah digunakan karena adanya tampilan grafis atau desain pada layar (Beal, 2018). Pendekatan terhadap usability dapat digunakan untuk mengetahui pengalaman pengguna seperti ketertarikan, kemudahan dan kenyamanan pengguna saat menjalankan aplikasi karena menurut ISO 9241-11 usability adalah bentuk ukuran, sejauh mana sebuah produk dapat digunakan oleh pengguna untuk mencapai tujuan tertentu dengan efektivitas, efisiensi dan kepuasan dalam konteks penggunaan produk (Galitz, 2007).

Bila diartikan secara harfiah usability berarti kegunaan, dimana hal tersebut merujuk kepada kualitas saat dapat memberikan sesuatu yang baik. Istilah usability pertama kali dicetuskan oleh Bennett yang kemudian disempurnakan oleh Shackel, menurutnya usability adalah kapasitas untuk digunakan manusia dengan mudah dan efisien (Galitz, 2007). Dalam buku The Essential Guide to User Interface Design: An Introduction to GUI Design (Galitz, 2007), Quensenbery menyatakan bahwa usability dapat diukur dengan beberapa komponen yaitu 1) Effective yaitu kelengkapan dan akurasi yang didapat pengguna dalam mencapai tujuan yang diinginkan, 2) Efficient yaitu kecepatan dan akurasi yang didapat pengguna dalam menyelesaikan tugas, 3) Engaging yaitu sejauh mana warna dan gaya desain antarmuka membuat produk menyenangkan atau memuaskan pengguna saat digunakan, 4) Error tolerant yaitu seberapa baik desain dapat mencegah kesalahan dan membantu perbaikan dari hal-hal yang telah terjadi, 5) Easy to learn yaitu seberapa baik produk mendukung orientasi awal serta peningkatan pengetahuan terhadap kemampuannya

Selain kelima komponen di atas, Rubin \& Chisnell (2008) menyatakan bahwa terdapat beberapa tipe pengujian yang perlu dilakukan untuk menilai usability dalam sebuah produk. Pengujian dilakukan dengan menggunakan pendekatan product development lifecycle yang dapat dilihat dalam gambar 2, pendekatan tersebut dapat menggambarkan perbedaan dalam beberapa jenis pengujian.

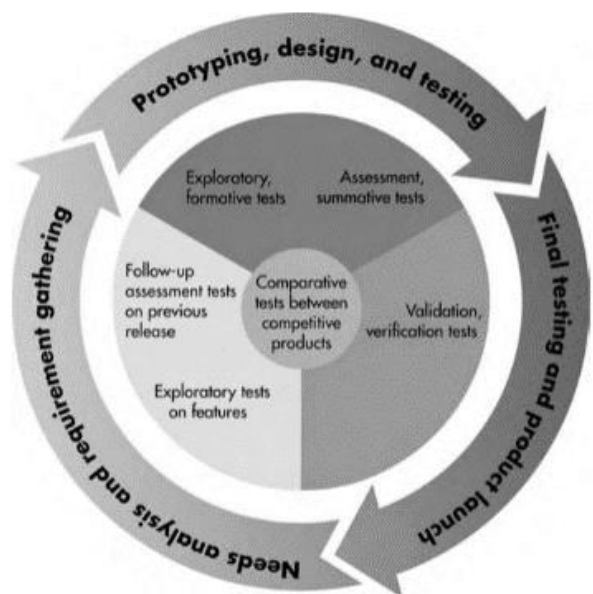

Gambar 2. Product Development Lifecycle dalam tes usability [Sumber: Rubin \& Chisnell, 2008]

Dari gambar diatas dapat dilihat bahwa terdapat empat jenis pengujian usability yaitu a) Exploratory or Formative Test: Pengujian dilakukan pada tahap awal pengembangan 
produk. Ekplorasi tes dapat menentukan luas interaksi antar partisipan dan menguji penguji untuk membangun konsep desain awal. Pengujian ini bersifat informal yang lebih fokus pada interaksi antara penguji dan partisipan. b) Assessment or Summative Test: Pengujian yang paling sederhana dan gampang dilakukan oleh penguji. Bertujuan untuk memperluas hasil temuan pada uji ekplorasi dengan mengevalusi usability pada level awal sistem operasi dalam produk. c) Validation or Verification Test: Pengujian dilakukan pada tahap akhir pengembangan produk. Bertujuan untuk mengevaluasi situs dibandingkan dengan standar kriteria yang telah ditetapkan seperti waktu standar pengerjaan skenario tugas dan skenario sukses. d) Comparisson Test: membandingkan suatu desain dengan desain lain.

Pada penelitian ini menggunakan pengujian dengan jenis pengujian komparasi. selain itu, Jacob Nielsen menyebutkan bahwa usability dapat ditentukan melalui lima komponen yaitu Learnability, Efficiency, Memorability, Errors dan Satisfaction (Nielsen, 2012). Sehingga dari ketiga aplikasi yang ada komparasi perlu dilakukan untuk mengetahui pengalaman pengguna atau user experience (UX) terhadap graphic user interface melalui usability.

Don Norman merupakan orang dibelakang berkembangnya istilah Pengalaman Pengguna. Pengalaman pengguna atau yang biasa disebut User Experience (UX) merupakan sebuah disiplin ilmu yang fokus pada pengalaman pengguna pada setiap sisi dari sebuah produk (Treder, 2013). Pengalaman pengguna sebenarnya sangat vital untuk setiap produk ataupun jasa, namun pengalaman pengguna menjadi kebutuhan yang sangat penting untuk web ataupun aplikasi karena web ataupun aplikasi merupakan teknologi yang memiliki kompleksitas tinggi, yang seringkali membuat pengguna merasa bingung. Sehingga, menurutnya User Experience (UX) adalah pengalaman yang didapatkan pengguna saat pengguna berinteraksi dengan produk, apakah pengguna saat berinteraksi mudah dalam menggunakannya, apakah mudah dipahami, apakah membuat produk lebih efisien dan efektif saat berinteraksi dengan pengguna (Garrett, 2011). Dalam bukunya Garrett juga menyebutkan adanya lima elemen dalam UX seperti terlihat dalam gambar 3.

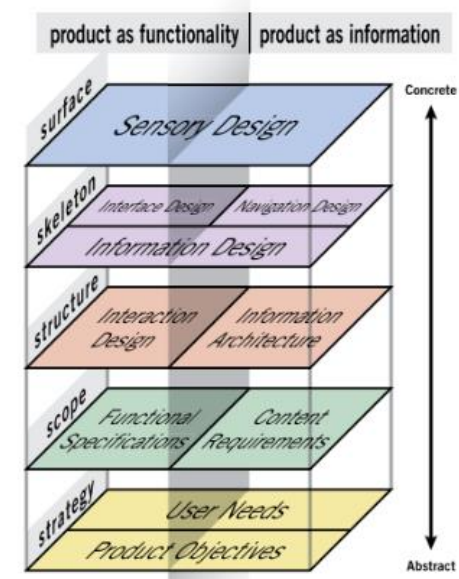

Gambar 3. UX Elemen

[Sumber: Garrett, 2011] 
Kelima elemen tersebut adalah (1) Strategy : Strategi informasi yang diperlukan adalah kebutuhan Pengguna dan tujuan dari dibuatnya produk, (2) Scope: Deskripsi spesifik tentang fungsi produk dan kebutuhan konten yang akan digunakan, (3) Structure : Desain yang interaktif dan arsitektur informasi yang dapat dimengerti dan direspon pengguna dengan baik, (4) Skeleton: Information design yang dibagi menjadi desain antarmuka dan desain navigasi, dan (5) Surface : desain visual yang memperhatikan pengalaman pengguna.

Adapun cara dalam mengukur user experience, menurut Namun Robert Rubinoff dapat dilakukan dengan mengukur empat elemen yang secara mutualisme saling bergantung dalam sebuah user interface. Keempat elemen tersebut adalah (a) Branding, berkaitan dengan seluruh tampilan visual dalam hal ini adalah desain, (b) Usability, berkaitan dengan interaktifitas pengguna terhadap komponen yang ada, (c) Functionality, berkaitan dengan hal-hal yang tak terlihat (back end), dan (d) Content, berkaitan dengan isi yang akan diletakkan, bisa berupa tulisan, gambar ataupun multimedia (Rubinoff, 2004).

\section{METODE PENELITIAN}

Untuk mengetahui usability user interface design terhadap pengalaman pengguna pada aplikasi ecommerce digunakan metode kuantitatif dengan metode pengumpulan data melalui penyebaran angket usability testing serta analisa data dengan menggunakan analisa System Usability Scale (SUS). Adapun tahapan yang akan dilakukan pada penelitian ini adalah:

1. Melakukan penyusunan untuk langkah-langkah yang akan dilakukan oleh pengguna sebelum mengisi usability testing. Saat menggunakan aplikasi ecommerce hal yang paling penting bagi pengguna adalah proses mencari barang yang diinginkan, melihat deskripsi barang yang diinginkan dan melakukan proses pembayaran. Proses tersebutlah yang akan menjadi landasan dalam langkah-langkah yang perlu dilakukan responden sehingga didapat langkah-langkah sebagai berikut:

a. Berada di Halaman Home. User yang mempunyai member Login : Memasukkan username dan password untuk login kedalam aplikasi. Bukan Member tidak perlu login.

b. Mencari produk yang diinginkan. Scroll ke atas dan ke bawah sampai menemukan barang yang diinginkan. User dapat menggunakan "search" untuk menemukan barang yang diinginkan atau juga dapat masuk kehalaman lain melalui menu.

c. Memilih dan membaca deskripsi barang yang diinginkan. Setelah memilih barang yang diinginkan. Baca informasi deskripsi dari barang yang user inginkan

d. Melihat Testimoni. User membaca testimoni yang diberikan pembeli sebelumnya pada barang di halaman komentar.

e. Memutuskan untuk membeli. User menekan tombol beli dan mengisi alamat serta memilih metode pembayaran yang akan digunakan.

2. Memilih responden. Responden dipilih secara acak dengan kondisi dimana responden sudah pernah menggunakan aplikasi yang menjadi variabel penelitian.

3. Tahapan Pengujian. Responden mengisi angket usability testing sesuai dengan sebelumnya mengikuti langkah-langkah yang telah dibuat. 
Tabel 1. Daftar pertanyaan SUS

[Sumber: Dokumentasi Penulis]

\begin{tabular}{|c|l|}
\hline No & \multicolumn{1}{|c|}{ Pertanyaan } \\
\hline 1 & Saya rasa saya akan sering menggunakan aplikasi ini \\
\hline 2 & Saya menemukan bahwa sistemnya kompleks \\
\hline 3 & Saya rasa aplikasi ini mudah digunakan \\
\hline 4 & $\begin{array}{l}\text { Saya rasa saya membutuhkan technical support untuk dapat menggunakan } \\
\text { aplikasi ini }\end{array}$ \\
\hline 5 & $\begin{array}{l}\text { Saya rasa berbagai bentuk fitur aplikasi yang ada didalam aplikasi telah } \\
\text { terintegrasi dengan baik satu sama lain }\end{array}$ \\
\hline 6 & Saya rasa ada terlalu banyak ketidakkonsistenan dalam aplikasi ini \\
\hline 7 & $\begin{array}{l}\text { Saya dapat membayangkan bahwa akan ada banyak orang yang belajar } \\
\text { menggunakan aplikasi ini secara cepat. }\end{array}$ \\
\hline 8 & Saya rasa aplikasi ini sangat rumit untuk digunakan \\
\hline 9 & Saya merasa sangat percaya diri saat menggunakan aplikasi ini \\
\hline 10 & $\begin{array}{l}\text { Saya harus belajar banyak hal terlebih dahulu sebelum saya dapat mulai } \\
\text { menggunakan aplikasi ini }\end{array}$ \\
\hline
\end{tabular}

4. Rekapitulasi hasil pengujian menggunakan SUS. Analisa SUS menggunakan skala penilaian 1 hingga $5(x)$ dengan bobot 0 hingga 4 dari 10 pertanyaan yang diberikan. Pertanyaan dibagi menjadi 2 yaitu pertanyaan yang bernada positif (diletakkan pada nomer pertanyaan 1,3,5,7 dan 9) dan pertanyaan bernada negatif (diletakkan pada nomer pertanyaan $2,4,6,8$ dan 10) (Ardiansyah \& Ghazali, 2016). Untuk Pertanyaan $1,3,5,7$ dan 9 nilai didapat dari skala penilaian dikurang $1(x-1)$ sedangkan Pertanyaan $2,4,6,8$, da 10 nilai didapat dari 5 dikurang skala penilaian ( $5-x$ ). Hasil penjumlahan dari nilai score dikalikan dengan 2.5 untuk mendapatkan nilai SUS (Brooke, 1996). Rentang hasil penilaian yang digunakan untuk penelitian ini akan diterjemahkan menggunakan adjective scale seperti yang terlihat pada gambar 4 (Bangor, Kortum, $\&$ Miller, 2009) (Sauro, 2018).

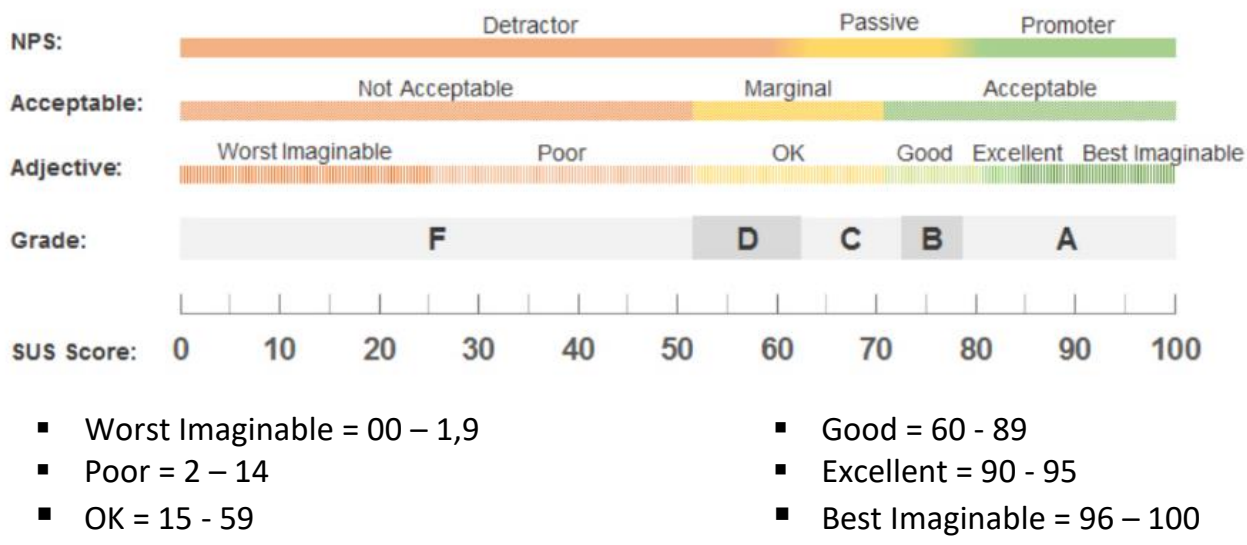

Gambar 4. Kategori Grades, Adjectives, Acceptability, dan NPS yang diasosiasikan dengan Nilai SUS. [sumber : https://measuringu.com/interpret-sus-score/] 


\section{ANALISA DAN PEMBAHASAN}

\subsection{Analisa Responden}

Dari hasil survei yang dilakukan terhadap 90 orang responden diketahui bahwasa $76,7 \%$ dari responden merupakan laki-laki, sedangkan sisanya $23.3 \%$ merupakan perempuan. Dilihat dari usia, responden memiliki rentang usia 18 - 43 tahun dengan pekerjaan mahasiswa, freelance, freelance fotografer, graphic designer, guru, dosen, Pegawai Negeri Sipil, dan wiraswasta. Setiap responden memiiliki akun ecommerce dengan pembagian sebagai berikut:

a. 1 akun ecommerce : Lazada (5 responden), Shopee (23 responden), Tokopedia (21 responden)

b. 2 akun ecommerce : Shopee, Lazada (4 responden), Tokopedia, Lazada(1 responden) dan Tokopedia, Shopee (25 Responden).

c. 3 akun ecommerce (Tokopedia, Shopee, Lazada) : 11 Responden

Namun jika dilihat secara keseluruhan dari sebaran akun yang dimiliki oleh pengguna, 63 responden memiliki akun shopee, 58 responden akun Tokopedia dan 21 responden memiliki akun Lazada seperti yang dapat terlihat di gambar 5 .

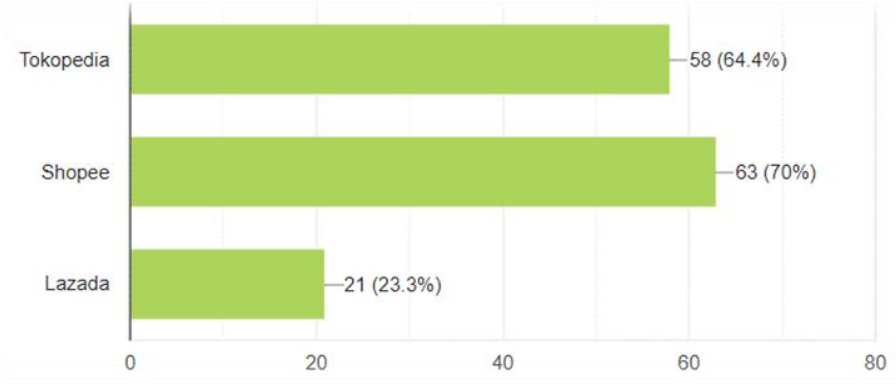

Gambar 5. Grafik sebaran akun yang digunakan oleh responden

[Sumber: Dokumentasi Penulis]

\subsection{Analisa Hasil Komparasi SUS}

Hasil analisa usability menggunakan SUS menunjukkan bahwa dengan penerjemahan yang diterjemahkan menggunakan adjective scale (Bangor, Kortum, \& Miller, 2009) (Sauro, 2018) ditemukan bahwa secara keseluruhan, Tokopedia, dan Shopee memiliki hasil SUS yang masuk dalam range nilai Good (Baik) yaitu sebesar 60 - 89 sedangkan Lazada memiliki hasus SUS yang masuk dalam range OK yaitu sebesar $15-59$.

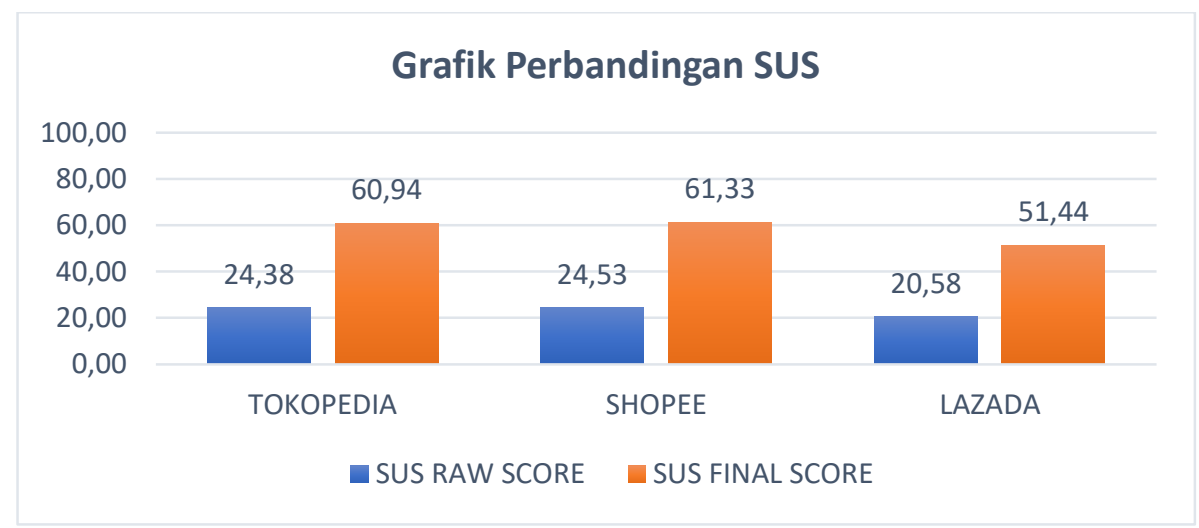

Gambar 6. Grafik perbandingan SUS Tokopedia, Shopee dan Lazada

[Sumber: Dokumentasi Penulis] 
Nilai yang dimiliki oleh setiap ecommarce didapat dari nilai survei yang telah dikonversi sesuai dengan bobotnya masing-masing, kemudian hasil rata-rata setiap responden menjadi nilai SUS RAW. Langkah terakhir untuk mendapatkan SUS Final score adalah dengan mengalikan SUS RAW 2,5. Hal ini dapat dilihat dalam gambar 6 dimana Tokopedia memiliki nilai SUS akhir 60,94, Shopee memiliki nilai 61,33, sedangkan Lazada memiliki nilai 51,44. Dari ketiga nilai yang didapat, Shopee memiliki nilai yang lebih tinggi dibandingkan Tokopedia namun masih berada dalam kategori range nilai yang sama sedangkan Lazada berada dikategori range nilai yang berbeda.

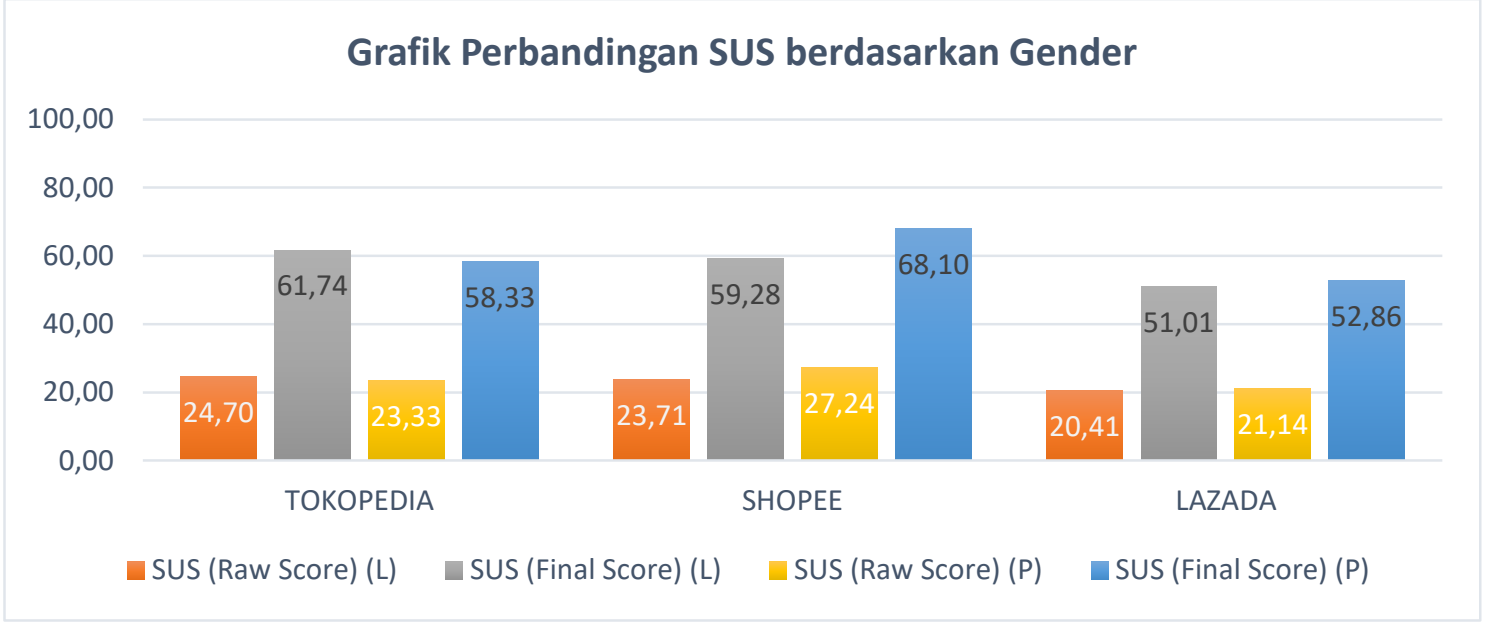

Gambar 7. Grafik perbandingan SUS Tokopedia, Shopee dan Lazada berdasarkan kategori Gender [Sumber: Dokumentasi Penulis]

Penulis juga mencoba memilah lebih dalam kembali hasil SUS dengan membedakan kategori lain yaitu dengan melihat SUS berdasarkan gender yaitu responden Pria dan wanita serta berdasarkan usia yaitu 18-22 dan 23-43 dengan estimasi 18-22 merupakan mahasiswa dan 23-43 merupakan responden yang telah bekerja. Dari kedua kategori di atas, seperti terlihat pada gambar 7, hasil perbandingan SUS berdasarkan gender, pada kategori responden Pria hanya Tokopedia yang berada dalam range nilai GOOD dengan SUS Final score sebesar 61,74 sedangkan Shopee dan Lazada berada dalam range nilai OK dengan nilai SUS 59,28 dan 51,01. Perbandingan SUS pada kategori Wanita menunjukkan hasil yang berbeda dimana Shopee berada dalam range nilai GOOD dengan SUS Final score sebesar 68,10 sedangkan Tokopedia dan Lazada berada dalam range nilai OK dengan nilai SUS 58,33 dan 52,86

Kemudian pada perbandingan SUS berdasarkan Usia, pada kategori usia 18 - 22 tahun Tokopedia dan Shopee berada dalam range nilai GOOD dengan SUS Final score sebesar 61,07 dan 61,48 sedangkan Lazada berada dalam range nilai OK dengan nilai SUS 50,78. Pada kategori usia 23 - 43 tahun hasil SUS tidak jauh berbeda, Tokopedia dan Lazada berada dalam range nilai GOOD dengan SUS Final score sebesar 60,69 dan 61,03 sedangkan Lazada berada dalam range nilai OK dengan nilai SUS 52,84 seperti terlihat pada gambar 8 . 


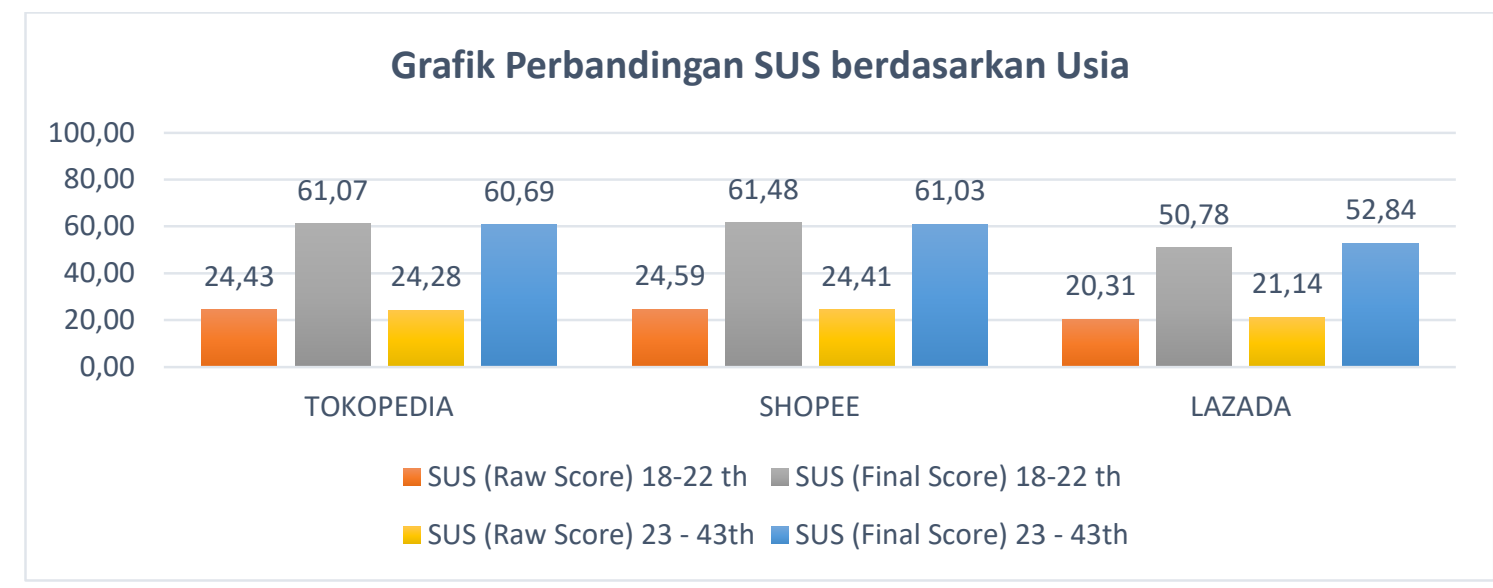

Gambar 8. Grafik perbandingan SUS Tokopedia, Shopee dan Lazada berdasarkan usia [Sumber: Dokumentasi Penulis]

\section{KESIMPULAN}

Dari analisa yang telah dilakukan, sebagai kesimpulan didapatkan bahwa pengalaman pengguna terhadap usability dari perbandingan beberapa aplikasi ecommarce (Tokopedia, Shopee dan Lazada) menggunakan SUS yang diterjemahkan menggunakan adjective scale berada pada range OK dan GOOD. Range ini memang mengagetkan penulis karena nilai yang didapat kurang mewakili ketiga aplikasi tersebut mengingat ketiga aplikasi ecommarce yang ada merupakan aplikasi yang berada pada urutan \#1, \#2 dan \#3 dalam Google Play pada kategori top free shoping. Hasil yang didapat SUS berdasarkan gender dan usia pun menghasilkan range yang sama yaitu OK dan GOOD.

\section{DAFTAR PUSTAKA}

Ardiansyah, \& Ghazali, M. I. (2016). Pengujian Usability User Interface dan User Experience Aplikasi E-Reader Skripsi Berbasis Hypertext. Jurnal IImiah Teknologi Informasi Terapan, 213 - 220.

Bangor, A., Kortum, P., \& Miller, J. (2009). Determining What Individual SUS Scores Mean: Adding an Adjective Rating Scale. Journal of Usability Studies, 4(3), 114123.

Beal, V. (2018). GUI - graphical user interface. Retrieved 01 08, 2018, from https://www.webopedia.com/TERM/G/Graphical_User_Interface_GUI.html

Brooke, J. (1996). SUS - A quick and dirty usability scale. In P. W. Jordan, B. Thomas, B. A. Weerdmeester, \& I. L. McClelland, Usability Evaluation in Industry (p. 189). London: Taylor \& Francis Ltd.

Fajrina, H. N. (2014). PERUSAHAAN RINTISAN : Kisah Pendiri Tokopedia yang Sempat Diremehkan. Retrieved January 3, 2018, from https://www.cnnindonesia.com/teknologi/20141210165312-185-

17281/kisah-pendiri-tokopedia-yang-sempat-diremehkan

Fihri, H. (2018). Universitas Dian Nuswantoro. Retrieved June 26, 2019, from http/:www.dinus.ac.id

Galitz, W. O. (2007). The Essential Guide to User Interface Design (Third Edition ed.). Indianapolis, Indiana: Wiley Publishing, Inc. 
Garrett, j. J. (2011). The Elements of User Experience : User-Centered Design for the Web and Beyond (Second Edition ed.). United States of America: new Riders.

Gianov, I. (2017). 7 Ecommerce Indonesia Terpopuler untuk Tujuan Kariermu Berikutnya. Retrieved 04 04, 2018, from https://glints.id/lowongan/ecommerce-indonesiaterpopuler/

Kinasih, R. (2017). ECOMScape 2017: Indonesia's Ever Changing Ecommerce Landscape. Retrieved 12 19, 2017, from https://ecommerceiq.asia/indonesia-ecommercelandscape-2017/?utm_source=country\%20page

Maity, R., Madrosiya, A., \& Bhattacharya , S. (2016). A Computational Model to Predict Aesthetic Quality of Text Elements of GUI . Procedia Computer Science , 84, 152 $-159$.

Morville, P. (n.d.). Usability : USER EXPERIENCE (UX) TOPIC OVERVIEW/DEFINITION. Retrieved 03 14, 2018, from https://www.interactiondesign.org/literature/topics/usability

Nielsen, J. (2012). Usability 101: Introduction to Usability. Retrieved 3 14, 2018, from https://www.nngroup.com/articles/usability-101-introduction-to-usability/

Putri, F. D. (2013). BISNIS E-COMMERCE: Lazada Akan Luncurkan Aplikasi Mobile. Retrieved January 3, 2018, from http://industri.bisnis.com/read/20130408/105/7302/bisnis-e-commercelazada-akan-luncurkan-aplikasi-mobile

Racholova, E. (2016). User Experience Desain Fundamentals.

Rubin, J., \& Chisnell, D. (2008). How to Plan, Design, and (Second Edition ed.). Indianapolis, Indiana: Wiley Publishing, Inc.

Rubinoff, R. (2004). How To Quantify The User Experience. Retrieved April 12, 2018, from https://www.sitepoint.com/quantify-user-experience/

Sauro, J. (2018). 5 WAYS TO INTERPRET A SUS SCORE. Retrieved August 15, 2019, from MeasuringU: https://measuringu.com/interpret-sus-score/

tokopedia. (2018). Tokopedia, membangun Indonesia lebih baik lewat Internet. Retrieved January 3, 2018, from https://www.tokopedia.com/about

Treder, M. (2013). UX Design for Startups. UXPin.

Yusuf, O. (2014). Tokopedia Sediakan Aplikasi di Android. Retrieved January 3, 2018, from http://tekno.kompas.com/read/2014/06/14/1814368/Tokopedia. Sediakan.Aplikasi.di.Android 